\title{
DUKUNGAN SOSIAL ORANG TUA, KONSEP DIRI DAN MOTIVASI BERPRESTASI MAHASISWA DI MASA PANDEMI COVID 19
}

\author{
Fredericksen Victoranto Amseke ${ }^{1}$, Marlen Angela Daik², Doni Ariani Leowandri Liu ${ }^{3}$ \\ ${ }^{1}$ Program Studi Pendidikan Kristen Anak Usia Dini, Institut Agama Kristen Negeri (IAKN) Kupang \\ Email: dedyamseke@gmail.com \\ ${ }^{2}$ Program Studi Manajemen Pendidikan Kristen, Institut Agama Kristen Negeri (IAKN) Kupang \\ Email: dedyamseke@gmail.com \\ ${ }^{3}$ Program Studi Pendidikan Agama Kristen, Institut Agama Kristen Negeri (IAKN) Kupang \\ Email: dedyamseke@gmail.com
}

Masuk : 28-11-2020, revisi: 06-04-2021, diterima untuk diterbitkan : 25-04-2021

\begin{abstract}
Motivation achievement is a crucial thing for students during the process of online learning in the pandemic COVID19 (coronavirus disease) as an ability to encourage an individual to achieve self-actualization and optimal learning outcomes. Motivation achievement is influenced by parental social support as an external factor and self-concepts as an internal factor. Therefore, this research aims to examine the influence of parental social-support and selfconcept toward students' motivation achievement in the pandemic COVID-19. This research used a quantitative method. The data were collected using parental social support scale, the self-concept scale and motivation achievement scale. The population in this research consists of 121 freshman year 2020 of Christian Early Childhood Education department in Institute of Christian State Kupang. The sample technique used in this research is accidental sampling with multiple regression analysis. The result proved that parental social support and self-concept have a positive influence and significant toward achievement motivation with $71.8 \%$. Parental social support contributed $23.4 \%$ and self-concept contributed $48.4 \%$ toward achievement motivation. The higher the role of parents' social support and self-concept, the higher the achievement motivation of students during the pandemic COVID 19.
\end{abstract}

Keywords: Parental Social Support, Self-Concept, Achievement Motivation.

\begin{abstract}
ABSTRAK
Motivasi berprestasi bagi mahasiswa sangat penting dalam proses pembelajaran daring di masa pandemi COVID-19 (coronavirus disease) sebagai kemampuan yang mendorong individu mencapai aktualisasi diri dan hasil belajar yang optimal. Motivasi berprestasi dipengaruhi oleh dukungan sosial orang tua sebagai faktor eksternal dan faktor internal yaitu konsep diri. Oleh karena itu, penelitian ini bertujuan untuk menguji pengaruh dukungan sosial orang tua dan konsep diri terhadap motivasi berprestasi mahasiswa di masa pandemi COVID-19. Penelitian ini menggunakan metode kuantitatif. Alat pengumpulan data menggunakan skala dukungan sosial orang tua, skala konsep diri dan skala motivasi berprestasi. Partisipan dalam penelitian ini berjumlah 121 mahasiswa pada program studi Pendidikan Kristen Anak Usia Dini di Institut Agama Kristen Negeri Kupang tahun 2020. Teknik analisis data menggunakan analisis regresi berganda. Hasil penelitian ini membuktikan bahwa dukungan sosial orang tua dan konsep diri berpengaruh positif dan signifikan terhadap motivasi berprestasi sebesar 71,8\%. Dukungan sosial orang tua berkontribusi $23,4 \%$ dan konsep diri berkontribusi 48,4\% terhadap motivasi berprestasi. Semakin tinggi peran dukungan sosial orang tua dan konsep diri maka dapat meningkatkan motivasi berprestasi mahasiswa di masa pandemi COVID-19.
\end{abstract}

Kata Kunci: Dukungan Sosial Orang Tua, Konsep Diri, Motivasi Berprestasi.

\section{PENDAHULUAN}

Pada awal tahun 2020, dunia dilanda dengan virus yang disebut dengan COVID-19 (Coronavirus Disease 2019) yang pertama kali ditemukan di kota Wuhan, China pada akhir Desember 2019. Dengan status penyebaran COVID-19 yang begitu cepat di semua negara maka organisasi kesehatan dunia (WHO) menyatakan wabah COVID-19 sebagai darurat kesehatan masyarakat secara internasional karena menimbulkan resiko kematian yang tinggi terutama bagi negara-negara dengan sistem pelayanan kesehatan yang rentan (Sohrabi et al.,2020). 
Dampak pandemi COVID-19 tidak hanya berpengaruh pada aspek kesehatan, tetapi juga berpengaruh pada berbagai lini kehidupan khususnya pada dunia pendidikan. Menurut Abidah et al. (2020) dampak penyebaran COVID-19 kini mulai memasuki dunia pendidikan di institusiinstitusi pendidikan sehingga diharapkan untuk tidak melaksanakan kegiatan seperti biasanya hal ini diharapkan untuk mengurangi penyebaran COVID-19.

Adapun upaya pemerintah Indonesia mengurangi penyebaran COVID-19 adalah menerapkan aturan pembatasan sosial berskala besar (PSBB) untuk warga dapat melakukan social distancing dan bahkan physical distancing. Tempat-tempat yang memungkinkan terjadinya kerumunan dan kontak fisik seperti sekolah dan kampus untuk melaksanakan proses pembelajaran secara daring bagi siswa dan mahasiswa untuk belajar secara online dari rumah masing-masing.

Motivasi yang paling utama dalam pembelajaran online adalah motivasi berprestasi. Menurut Santrock (2003), motivasi berprestasi merupakan keinginan untuk menyelesaikan sesuatu dalam mencapai suatu standar kesuksesan, dan melakukan suatu usaha demi mencapai suatu tujuan. Sementara itu, Winkel (1992) menuliskan motivasi berprestasi adalah daya penggerak dalam diri individu untuk memperoleh keberhasilan dan melibatkan diri dalam kegiatan di mana keberhasilannya tergantung pada usaha pribadi dan kemampuan yang dimilikinya. Mengingat pentingnya motivasi berprestasi bagi keberhasilan mahasiswa maka setiap mahasiswa diharapkan memiliki motivasi berprestasi yang tinggi.

Pembelajaran online dilakukan dengan sistem belajar jarak jauh dengan menggunakan media baik media cetak (modul) maupun non cetak (audio/video), internet dengan aplikasi Zoom meeting, Google meet, Google Classroom, Edmodo, WhatsApp dan Email. Oleh karena itu, setiap dosen dapat menjalankan tugas pengajaran dengan mengunggah konten pembelajaran seperti bahan bacaan, video pembelajaran, ataupun tautan materi yang tersedia di web ke aplikasi pembelajaran yang digunakan agar mahasiswa dapat memberikan tanggapan atau pertanyaan melalui fitur chat yang disediakan ataupun menggunakan WhatsApp.

Pada kenyataannya dalam pembelajaran online ada mahasiswa kurang aktif dalam menyampaikan aspirasi dan pemikirannya sehingga dapat mengakibatkan pembelajaran yang menjenuhkan. Seorang mahasiswa mengalami kejenuhan dalam belajar akan memperoleh ketidakmajuan dalam hasil belajar. Oleh karena itu, mahasiswa perlu menumbuhkan motivasi dalam diri sendiri untuk melakukan aktivitas belajar. Hal ini senada dengan pendapat Suryabrata (2006) bahwa motivasi sebagai dorongan atau dukungan penyemangat bagi individu untuk menambah suatu perilaku tertentu. Dengan adanya dorongan dari orang lain maka individu dapat memiliki prestasi yang lebih giat, tekun dan lebih fokus dalam proses belajarnya. (Adi, 1994).

Ada berbagai macam faktor yang memengaruhi motivasi berprestasi, yaitu faktor intrinsik seperti cita-cita, kepribadian, konsep diri dan inteligensi sedangkan faktor ekstrinsik seperti lingkungan keluarga, sekolah/kampus, masyarakat dan budaya. Dalam penelitian ini memilih dua faktor, yaitu dukungan sosial orangtua dan konsep diri. Variabel dukungan sosial orang tua sangat penting karena orangtua merupakan tempat anak berinteraksi untuk pertama kalinya. Selain itu orang tua bertanggung jawab bagi perkembangan pendidikan anak, baik pendidikan informal maupun formal (Santrock, 2003).

Hasil penelitian Maqsud dan Coleman (1993) menunjukkan bahwa peranan orangtua dalam memberikan dukungan sosial terhadap anak berhubungan positif dan signifikan dengan motivasi berprestasi. Dalam pengertian bahwa semakin besar dukungan sosial orang tua semakin tinggi 
motivasi berprestasi anak. Dengan kata lain makin kecil dukungan sosial orangtua, makin rendah motivasi berprestasi anak. Selain itu Verkuyten et al. (2001), menemukan bahwa keluargakeluarga yang masih mempertahankan budaya kekerabatan. Dalam hubungan kekerabatan inilah dukungan sosial orangtua sangat berpengaruh terhadap motivasi berprestasi anak mereka. Motivasi berprestasi anak lebih berorientasi pada jenis motivasi berprestasi golongan atau kolektif (Duda \& Allison, Maehr \& Nicholls, Yu \& Yang, dalam Verkuyten et al. (2001). Berorientasi golongan atau kolektif mengandung pengertian bahwa individu melakukan sesuatu untuk memenuhi harapan dari orang lain, termasuk di dalamnya memenuhi harapan orangtua.

Hal ini dapat dilihat dari hasil penelitian yang dilakukan oleh Verkuyten et al. (2001) melalui tiga kali studi yang dilakukan terhadap anak-anak Turki dan anak-anak Belanda, ditemukan bahwa anak-anak dari keluarga Turki memiliki dukungan sosial yang lebih tinggi dibandingkan dengan dukungan sosial orangtua dari keluarga Belanda. Oleh karena itu hasil penelitiannya menunjukkan bahwa dukungan sosial orangtua dari anak-anak Turki berpengaruh positif dan signifikan terhadap motivasi berprestasi anak. Sebaliknya, dukungan sosial dari orangtua anak-anak Belanda tidak berpengaruh secara signifikan terhadap motivasi berprestasi anak, karena motivasi berprestasi anak-anak Belanda lebih didorong oleh faktor pribadi.

Di dalam kehidupan anak sebagian besar keluarga memberikan dukungan untuk berprestasi dan sukses terkait dengan harapan keluarga/orangtua. Crandall (Maqsud \& Coleman, 1993) menyatakan orangtua mempunyai pengaruh kuat pada pengembangan motivasi berprestasi anak mereka. Selanjutnya menurut McClelland dan Pilon (Maqsud \& Coleman, 1993) pengharapan orangtua terhadap masa depan anak-anak, serta anak belajar melalui pengamatan langsung adalah penting dalam pengembangan motivasi berprestasi mereka. Jadi anak-anak yang berprestasi, mempunyai inisiatif, dan daya saing diperkuat oleh orangtua mereka, lebih mungkin untuk berkembangnya motivasi berprestasi yang lebih tinggi (Spence \& Woollfolk, dalam Maqsud \& Coleman, 1993).

Dalam kajian selanjutnya, Paulson (dalam Santrock, 2003) mengungkapkan bahwa melalui model kombinasi pola asuh orangtua yang di dalamnya terdapat dukungan sosial orangtua akan mampu memberikan dukungan terhadap anak, hal ini akan membuat anak memiliki motivasi berprestasi yang tinggi. Hal ini senada dengan penelitian Amseke (2018) yang menemukan ada pengaruh yang positif dan signifikan dukungan sosial orang tua terhadap motivasi berprestasi siswa kelas VII di SMP Negeri 1 Biboki Kabupaten Timor Tengah Utara.

Selain dukungan sosial dari orang tua, konsep diri juga berpengaruh terhadap motivasi berprestasi. Menurut Burns (1993) konsep diri adalah hubungan antara sikap dan keyakinan tentang diri sendiri. Lebih lanjut Brooks (Wiprana, 2006) mendefinisikan konsep diri sebagai persepsi tentang diri sendiri, secara fisik, sosial dan psikologis yang diperoleh berdasarkan pengalaman dan interaksi dengan lingkungan.Pada dasarnya konsep diri bersifat dinamis, artinya dapat berubah melalui hasil belajar dari individu. Menurut Calhoun dan Accocella (1995) konsep diri merupakan ciptaan sosial dan hasil belajar individu melalui interaksinya dengan orang lain. Dengan demikian konsep diri merupakan pandangan individu terhadap diri sendiri yang diperoleh melalui pengalaman interaksinya dengan lingkungan sosial yang membuahkan penilaian terhadap dirinya.

Konsep diri yang positif akan memudahkan orang untuk berhasil mengembangkan diri. Sejalan dengan pendapat Heckhausen (dalam Mintabae, 2010) yang menuliskan faktor-faktor yang mempengaruhi motivasi berprestasi adalah konsep diri positif. Hal ini didukung dengan penelitian yang dilakukan oleh Wigfield dan Eccles (Zanobini \& Usai, 2002) yang menemukan bahwa 
konsep diri berpengaruh terhadap motivasi berprestasi, jika individu mempunyai konsep diri positif maka motivasi berprestasinya akan menjadi lebih tinggi, dan sebaliknya jika individu memiliki konsep diri negatif maka motivasi berprestasi menjadi rendah. Selanjutnya menurut Pudjijogyanti (dalam Mintabae, 2010), individu yang memiliki pandangan negatif terhadap dirinya mengharapkan tingkat keberhasilan yang dicapai hanya pada taraf yang rendah. Patokan yang rendah tersebut menyebabkan individu tidak mempunyai motivasi berprestasi. Sedikit berbeda dengan hasil penelitian yang telah ditemukan oleh Zanobini dan Usai (2002) yang menunjukkan bahwa motivasi berprestasi tidak dipengaruhi oleh konsep diri akademis.

Berdasarkan latar belakang yang telah diuraikan maka rumusan masalah dalam penelitian ini adalah bagaimana pengaruh dukungan sosial orang tua dan konsep diri terhadap motivasi berprestasi mahasiswa semester baru 1 program studi Pendidikan Kristen Anak Usia Dini di Institut Kristen Negeri (IAKN) Kupang di masa pandemi COVID-19.

\section{METODE PENELITIAN}

Metode penelitian yang digunakan dalam penelitian adalah kuantitatif. Partisipan dalam penelitan ini berjumlah 121 mahasiswa semester I tahun 2020 pada program studi Pendidikan Kristen Anak Usia Dini di Institut Kristen Negeri (IAKN) Kupang. Variabel yang digunakan dalam penelitian ini adalah dukungan sosial orang tua, konsep diri dan motivasi berprestasi. Metode pengumpulan data yang digunakan adalah skala dukungan sosial orang tua mengacu pada aspek dukungan sosial menurut Sarafino dan Smith (2011) yang memiliki 20 butir terbukti valid dengan menggunakan uji koefisien corrected item total correlation, nilai reliabilitas dengan teknik alpha cronbach sebesar 0,881. Skala konsep diri mengacu pada aspek konsep diri menurut Partosuwido (1992) yang memiliki 14 butir terbukti valid dengan menggunakan uji koefisien corrected item total correlation, nilai reliabilitas dengan teknik alpha cronbach sebesar 0,905. Skala motivasi berprestasi yang mengacu pada aspek motivasi berprestasi menurut McClleland (dalam Luthans, 2011) yang memiliki 29 butir yang valid dengan uji koefisien corrected item total correlation dan nilai reliabilitas dengan teknik alpha cronbach sebesar 0,929. Teknik analisis data adalah analisis regresi berganda dengan metode analisis deskriptif. Data diolah menggunakan program statistic SPSS 22.0

\section{HASIL DAN PEMBAHASAN}

Deskripsi statistik data dukungan sosial orang tua, konsep diri dan motivasi berprestasi mahasiswa sebagai berikut:

Tabel 1.

Hasil Kategori Dukungan Sosial Orang Tua

\begin{tabular}{cccc}
\hline Kategori & Range & N & $\%$ \\
\hline Sangat Rendah & $27-37$ & 5 & 4,1 \\
\hline Rendah & $38-48$ & 7 & 5,7 \\
\hline Tinggi & $49-59$ & 37 & 30,6 \\
\hline Sangat Tinggi & $60-70$ & 72 & 59,6 \\
\hline
\end{tabular}

Tabel 1 menunjukkan penyebaran skor dukungan sosial orang tua berdasarkan penilaian mahasiswa. Diperoleh skor sangat tinggi sebesar 59,6\% (72 mahasiswa), kategori tinggi sebesar $30,6 \%$ (37 mahasiswa), kategori rendah sebesar 5,7\% (7 mahasiswa), dan kategori sangat rendah sebesar 4,1\% (5 mahasiswa). Perbedaan skor dukungan sosial orang tua berkembang sebagai respon penilaian mahasiswa sebagai remaja dalam berinteraksi dengan orang tuanya sebagai ikatan sosial emosi dalam keluarga. Menurut Amseke (2018) dukungan sosial orang tua berfungsi 
memberikan penguatan bagi anak dalam menumbuhkan rasa aman dalam melakukan partisipasi aktif, memberikan kasih sayang, perhatian, penghargaan dan eskplorasi dalam kehidupan, yang pada akhirnya meningkatkan rasa percaya diri pada siswa untuk menghadapi situasi baru dan tantangan di dalam kehidupannya. Oleh karena itu, pentingnya peran dukungan sosial orang tua yang bernilai untuk anak sebagai mahasiswa dalam menghadapi pembelajaran online di masa pandemi COVID-19.

Tabel 2.

Hasil Kategori Konsep Diri

\begin{tabular}{cccc}
\hline Kategori & Range & N & $\%$ \\
\hline Sangat Rendah & $39-51$ & 6 & 5 \\
\hline Rendah & $52-64$ & 17 & 14 \\
\hline Tinggi & $65-77$ & 46 & 38 \\
\hline Sangat Tinggi & $78-90$ & 52 & 43 \\
\hline
\end{tabular}

Pada tabel 2 menunjukkan penyebaran skor konsep diri mahasiswa. Diperoleh skor sangat tinggi sebesar 43\% (52 mahasiswa), kategori tinggi sebesar 38\% (46 mahasiswa), kategori rendah sebesar 14\% (17 mahasiswa), dan kategori sangat rendah sebesar 5\% (6 mahasiswa). Hasil ini menggambarkan bahwa mahasiswa memiliki konsep diri yang positif. Hal ini dapat dilihat dari persepsi mahasiswa memandang dirinya sendiri baik fisik, psikis maupun sosialnya secara positif serta memiliki pemahaman yang baik tentang dirinya. Menurut Stanes (dalam Burns, 1993) konsep diri sebagai kesadaran individu mengenai konsep, evaluasi termasuk respon kognisi individu terhadap persepsi dan pemahaman diri individu.

Tabel 3.

Hasil Kategori Motivasi Berprestasi

\begin{tabular}{cccc}
\hline Kategori & Range & N & $\%$ \\
\hline Sangat Rendah & $83-94$ & 15 & 12,4 \\
\hline Rendah & $95-106$ & 28 & 23,1 \\
\hline Tinggi & $107-118$ & 40 & 33,1 \\
\hline Sangat Tinggi & $119-130$ & 38 & 31,4 \\
\hline
\end{tabular}

Pada tabel 3 menunjukkan penyebaran skor motivasi berprestasi mahasiswa. Diperoleh skor sangat tinggi sebesar 31,4\% (38 mahasiswa), kategori tinggi sebesar 33,1\% (40mahasiswa), kategori rendah sebesar 23,1\% (28 mahasiswa), dan kategori sangat rendah sebesar 12,4\% (15 mahasiswa). Hasil ini menunjukkan bahwa mahasiswa memiliki keinginan atau hasrat yang sangat tinggi untuk mencapai suatu tujuan untuk berprestasi dalam pendidikan di perguruan tinggi dengan menyelesaikan tugas-tugas yang sulit, memiliki ide-ide kreatif dan mampu mengatasi segala rintangan serta keinginan untuk mencapai kesuksesan pada yang yang dilakukannya.

Tabel 4.

Ringkasan Hasil Analisis Regresi Berganda Uji Simultan F

\begin{tabular}{lcccc}
\hline \multicolumn{1}{c}{ Hubungan } & F & P & Keterangan & Kesimpulan \\
\hline $\begin{array}{l}\text { Dukungan Sosial Orang Tua, Konsep } \\
\text { Diri dengan Motivasi Berprestasi }\end{array}$ & 150,479 & 0,000 & $0,000<0,05$ & Hipotesis diterima
\end{tabular}


Tabel 5.

Ringkasan Hasil Nilai Koefisien Determinasi (R Square)

\begin{tabular}{ccccc}
\hline Model & R & R Square & Adjusted R Square & Std. Error of the Estimate \\
\hline 1 & $.848^{\mathrm{a}}$ & .718 & .714 & 7.58262 \\
\hline
\end{tabular}

Tabel 4 dan tabel 5 menunjukkan ringkasan hasil uji hipotesis secara simultan (F) yang menunjukkan bahwa ada hubungan positif yang signifikan antara dukungan sosial orang tua dan konsep diri dengan motivasi berprestasi mahasiswa dengan nilai $\mathrm{p}=0,000$ dan $\mathrm{F}=150,479$ dengan $\mathrm{R}$ Square $=0,718$. Sumbangan efektif variabel dukungan sosial orang tua dan konsep diri terhadap motivasi berprestasi mahasiswa sebesar $71,8 \%$ dan sisanya $28,2 \%$ diterangkan oleh variabel yang lain.

Tabel 6.

Ringkasan Hasil Analisis Regresi Berganda Uji Parsial (Uji t)

\begin{tabular}{lccccc}
\hline \multicolumn{1}{c}{ Hubungan } & t & P & Keterangan & Kesimpulan \\
\hline $\begin{array}{l}\text { Dukungan Sosial Orang } \\
\text { dengan Motivasi Berprestasi }\end{array}$ & Tua & 4,409 & 0,000 & $0,000<0,05$ & Hipotesis diterima \\
$\begin{array}{l}\text { Konsep Diri } \\
\text { dengan Motivasi Berprestasi }\end{array}$ & 8,281 & 0,000 & $0,000<0,05$ & Hipotesis diterima \\
\hline
\end{tabular}

Tabel 6 merupakan ringkasan hasil uji hipotesis secara parsial $(\mathrm{t})$ yang menunjukkan bahwa ada hubungan positif yang signifikan dukungan sosial orang tua dengan motivasi berprestasi yang diperoleh nilai $\mathrm{p}=0,000$ dengan $\mathrm{t}=4.409$ dan konsep diri ada hubungan positif yang signifikan tua dengan motivasi berprestasi yang diperoleh nilai $\mathrm{p}=0,000$ dengan $\mathrm{t}=8.281$. Dukungan sosial orang tua memiliki kontribusi terhadap motivasi berprestasi sebesar $23,4 \%$ sedangkan konsep diri terhadap motivasi berprestasi sebesar $48,4 \%$.

Penelitian ini membuktikan hipotesis bahwa ada pengaruh dukungan sosial orang tua dan konsep diri terhadap motivasi berprestasi mahasiswa semester I tahun 2020 Program Studi Pendidikan Kristen Anak Usia Dini di Institut Kristen Negeri (IAKN) Kupang. Penelitian ini sesuai dengan hasil pembuktian empiris oleh penelitian Mintabe (2010) yang menemukan pengaruh secara simultan dukungan sosial orang tua dan konsep diri terhadap motivasi berprestasi pada mahasiswa Universitas Halmahera dengan diperoleh nilai $F_{\text {hitung }}$ sebesar 28.926 dengan tingkat signifikansi 0.000 dimana Dukungan sosial orangtua memberi pengaruh yang signifikan sebesar $9,4 \%$ ( $\beta=$ $0.206)$ dan konsep diri memberi pengaruh yang signifikan sebesar $32 \%(\beta=0.519)$. Selain itu, penelitian Jannah (2018) membuktikan dukungan sosial orang tua dan konsep diri memiliki hubungan positif dengan motivasi berprestasi mahasiswa Aceh di malang dengan nilai $r$ sebesar 0,784 dan koefisien determinasi ( $R$ Square) sebesar 0.584 yang berarti nilai sumbangan pengaruh sebesar 58\% pengaruh sedangkan sisa $42 \%$ dipengaruhi oleh faktor lain.

Dukungan sosial orangtua memiliki peran penting dalam meningkatkan dan mempertahankan motivasi berprestasi mahasiswa. Dukungan sosial orangtua yang terus-menerus diberikan dapat membuat mahasiswa terdorong untuk meningkatkan motivasi berprestasi.Hasil penelitian Amseke (2018) menunjukkan bahwa dukungan sosial orangtua berpengaruh positif terhadap motivasi berprestasi siswa kelas VII di SMP Negeri 1 Biboki Kabupaten Timor Tengah Utara-Kefamenanu diperoleh nilai korelasi (r) sebesar 0,719 dengan koefisien determinasi $\left(\mathrm{R}^{2}\right)$ sebesar 0,517, menggambarkan sumbangan pengaruh dukungan sosial orang tua terhadap motivasi berprestasi sebesar $51,7 \%$, sedangkan sisanya 48,3\% dipengaruhi oleh variabel lain. 
Dalam suatu kesempatan penelitian Putra dan Nurhadianti (2020) menemukan adanya hubungan yang signifikan dengan arah positif antara dukungan sosial orang tua dengan motivasi berprestasi siswa kelas XII SMAN 6 Tambun Selatan dengan sampel sebanyak 182 siswa yang membuktikan nilai koefisien korelasi $r$ sebesar 0,360 dan $p<0,05$ yang berarti semakin tinggi dukungan sosial orang tua, maka semakin tinggi pula motivasi berprestasi yang dimiliki siswa.Sementara itu, hasil penelitian Dendi (2014) menemukan adanya hubungan yang signifikan dengan arah positif antara dukungan sosial orang tua dengan motivasi berprestasi.

Berbeda dengan hasil penelitian Putri (2014) yang membuktikan bahwa dukungan sosial (orang tua, pelatih dan teman) memiliki kaitan yang lebih erat dengan motivasi berprestasi olahraga dibandingkan dengan motivasi berprestasi akademik. Sementara itu, penelitian Setyaningrum (2015) menemukan bahwa dukungan sosial orang tua berpengaruh secara positif dan signifikan terhadap motivasi berprestasi siswa kelas V Sekolah Dasar di Gugus Hasanudin Kabupaten Cilacap tahun ajaran 2014/2015. Dukungan sosial orang tua berpengaruh sebesar $32.1 \%$ terhadap motivasi berprestasi siswa. Hal ini dibuktikan dengan nilai $F_{\text {hitung }}=15.042>F_{\text {tabel }}=2.44$ dan $\mathrm{R}^{2}$ $=0.321$. Dapat diartikan bahwa semakin tinggi tingkat dukungan sosial orang tua, maka tingkat motivasi berprestasi siswa semakin tinggi.

Selanjutnya hasil penelitian sehubungan dengan dukungan sosial orangtua menunjukkan bahwa orang tua mempunyai pengaruh kuat pada pengembangan motivasi berprestasi anak-anak. Anak yang berprestasi, mempunyai inisiatif, dan daya saing diperkuat oleh orang tua mereka, sehingga memungkinkan meningkatnya motivasi berprestasi. Demikian pula, harapan orang tua dan anak belajar melalui pengamatan adalah penting dalam pengembangan motivasi berprestasi anak-anak (Crandall \& Sinkeldam; Rosen \& D'Andrade; Spence; Woollfolk; McClelland \& Pilon, dalam Maqsud \& Coleman, 1993). Beberapa penelitian tentang dukungan sosial menunjukkan bahwa dukungan sosial mempunyai pengaruh positif bagi individu dalam menjalani kehidupannya. Seperti meningkatkan perasaan optimis dalam menghadapi masa depan, menambah kesejahteraan psikologis dan kesehatan serta mengurangi pengaruh negatif yang merugikan (House \& Kahn; Johnson \& Johnson; Rodin \& Salovey; Indarjati; Farhati \& Rosyid, dalam Mintabae, 2010).

Selain dukungan sosial orangtua, konsep diri mempunyai peran penting dalam motivasi berprestasi. Setiap individu mempunyai gambaran tentang dirinya sendiri. Keberhasilan dalam memiliki konsep diri yang positif akan membuat individu mampu memiliki gambaran yang baik terhadap dirinya, dengan demikian maka individu memiliki motivasi berprestasi yang tinggi. Pendapat tersebut didukung oleh hasil penelitian dari Wigfield dan Eccles (Zanobini \& Usai, 2002) yang menyatakan bahwa konsep diri berpengaruh terhadap motivasi berprestasi, terlebih jika yang terbentuk adalah konsep diri positif akan meningkatkan motivasi berprestasi anak. Menurut Santrock (2003) bahwa pengaruh motivasi intrinsik lebih kuat terhadap motivasi berprestasi, namun dalam konteks mahasiswa program studi pendidikan kristen anak usia dini di IAKN Kupang ternyata motivasi ekstrinsik yaitu dukungan sosial orangtua masih cukup berpengaruh terhadap motivasi berprestasi mahasiswa.

Selanjutnya perlu disadari bahwa pada umumnya mahasiswa telah berada pada periode remaja akhir. Keadaan ini sama dengan pendapat Partosuwido (1992), bahwa mahasiswa pada umumnya berada pada tahap remaja akhir atau dewasa awal. Di usia ini individu mengalami suatu proses yang wajar dalam perkembangan otonomi. Dalam proses tersebut individu ingin mengatasi sendiri persoalan yang dihadapinya, namun terkadang individu mengalami konflik antara kebebasan dan ketergantungan dengan lingkungan. Keadaan inilah yang mempengaruhi tingkat signifikansi dukungan orangtua terhadap motivasi berprestasi. Dapat dikatakan bahwa pada usia remaja akhir 
semakin kecil pengaruh dukungan sosial orangtua terhadap motivasi berprestasi individu. Sehingga untuk memperoleh prestasi yang lebih baik diperlukan dukungan orangtua namun juga individu harus berusaha dengan giat dan mengembangkan seluruh kemampuan yang dimiliki.

Dalam suatu kesempatan Steinberg (dalam Karma, 2002) menjelaskan bahwa pada periode ini remaja mulai memiliki otonomi diri atau adanya keinginan untuk semakin mandiri, dengan mengambil keputusan dan tanggung jawab lebih pada diri sendiri. Walaupun demikian kondisi ini tergantung dari model dukungan sosial orangtua terhadap anak dan perubahan-perubahan kognitif anak.

Calhoun dan Acocella (1995) menuliskan bahwa sumber internal penting dalam pembentukan konsep diri adalah orangtua sebagai kontak sosial yang paling awal dan kuat yang dialami oleh individu. Selanjutnya Hurlock (1999) mengemukakan beberapa faktor yang mempengaruhi konsep diri diantaranya cita-cita dan usia kematangan, bila orangtua masih memperlakukan individu sebagai anak-anak dan tidak sesuai dengan kematangan usia, maka individu akan memiliki konsep diri yang kurang baik atau konsep diri negatif sehingga tingkat motivasi berprestasi akan rendah.

Hal yang diungkapkan di atas jelas terjadi dalam kehidupan sebagian besar mahasiswa di IAKN Kupang, dimana orangtua kurang melibatkan anak dalam pengambilan keputusan untuk memilih tempat kuliah. Namun ternyata ini tidak mempengaruhi konsep diri mahasiswa. Hal ini terjadi oleh karena individu (mahasiswa) telah berada di usia remaja akhir dan memiliki konsep dirinya yang positif. Menurut Grinder (dalam Mintabae, 2010), konsep diri yang telah terbentuk sejak masa kanak-kanak akan menjadi penting dalam usaha untuk mencapai konsep diri yang stabil di masa dewasa. Dengan konsep diri yang semakin stabil dapat mempengaruhi mahasiswa dalam mempersepsikan diri sendiri maupun lingkungan.

Menurut Partosuwido (1992) konsep diri merupakan salah satu faktor internal yang berpengaruh langsung terhadap sikap dan perilaku seseorang, terutama dalam hal motivasi berprestasi. Apabila individu memiliki konsep diri yang positif maka akan meningkatkan motivasi berprestasi. Sementara itu, dengan adanya dukungan sosial orangtua sebagai faktor internal yang berpengaruh terhadap motivasi berprestasi, dan didukung dengan konsep diri yang baik sebagai faktor internal, maka hal ini mendorong tingkat motivasi berprestasi dari seseorang secara khusus pada mahasiswa di IAKN yang sedang mengikuti pembelajaran online di masa pandemi COVID-19. Dengan demikian adanya faktor internal dan faktor eksternal maka motivasi berprestasi terus meningkat.

Pada akhirnya, dengan tetap meningkatkan dukungan sosial orangtua diharapkan mahasiswa dapat mempertahankan dan meningkatkan motivasi berprestasi. Selanjutnya, dengan memiliki konsep diri yang positif maka individu akan mampu meningkatkan motivasi berprestasi. Dengan demikian dukungan sosial orangtua dan konsep diri yang positif sangat penting untuk meningkatkan motivasi berprestasi mahasiswa di masa pandemi COVID-19

\section{KESIMPULAN}

Kesimpulan dalam penelitian ini bahwa terdapat pengaruh positif dan signifikan dukungan sosial orang tua dan konsep diri terhadap motivasi berprestasi mahasiswa semester I tahun 2020 program studi Pendidikan Kristen Anak Usia Dini di Institut Kristen Negeri (IAKN) Kupang. Diharapkan orang tua sebagai model dan mentor terbaik untuk remaja sebagai mahasiswa dengan menjalin relasi yang erat dan memberikan dukungan sosial melalui dukungan informasi, dukungan emosional, dukungan penghargaan, dukungan instrumental dan mahasiswa dapat memiliki konsep 
diri yang positif dengan keyakinan untuk melakukan tugas yang terbaik di dalam kegiatan akademik maupun non akademik yang bermanfaat untuk dapat meningkatkan motivasi berprestasi mahasiswa di masa pandemi COVID 19.

\section{REFERENSI}

Abidah, A., Hidaayatullaah, H. N., Simamora, R. M., Fehabutar, D., \& Mutakinati, L. (2020). The impact of Covid-19 to Indonesian education and its relation to the philosophy of "Merdeka Belajar." Studies in Philosophy of Science and Education, 1(1), 38-49.

Adi, I. R. (1994). Psikologi pekerja sosial dan ilmu kesejahteraan sosial, dasar-dasar pemikiran. PT Raja Grafindo.

Amseke, F. V. (2018). Pengaruh dukungan sosial orang tua terhadap motivasi berprestasi. Ciencies: Jurnal Penelitian dan Pengembangan Pendidikan, 1(1), 65-81.

Burns, R. B. (1993). Konsep diri. Arcan.

Calhoun, J.F \& Accocella, J.R. (1995). Psikologi tentang penyesuaian diri dan hubungan kemanusiaan (Satmoko Trans.). IKIP Semarang Press.

Dendi, R. F. P. (2014). Hubungan antara dukungan sosial orangtua dengan motivasi berprestasi pada siswa SMU Yayasan Pendidikan Islam 45 di Bekasi. [Skripsi, Universitas Persada Indonesia Y.A.I].

Hurlock, E. B. (1999). Psikologi perkembangan suatu pendekatan sepanjang rentang kehidupan $\left(5^{\text {th }}\right.$ ed.). Erlangga.

Jannah, M. (2018). Hubungan konsep diri dan dukungan sosial orang tua dengan motivasi berprestasi pada mahasiswa Aceh di Malang. [Skripsi, Universitas Islam Negeri Maulana Malik Ibrahim Malang].

Karma, I. N. (2002). Hubungan antara pola pengasuhan orang tua dan otonomi remaja (Studi tentang Remaja Pertengahan Pada Budaya Sasak di Kabupaten Lombok Barat. Jurnal Psikologi, (9), 1-17.

Luthans, F. (2011). Organizational behavior: An evidence-based approach (12 $\left.{ }^{\text {th }} \mathrm{ed}.\right)$. McGrawHill.

Maqsud, M., \& Coleman M. F. (1993). The role of parental interaction in achievement motivation. The Journal of Social Psychology, 133(6), 859-861. https://doi.org/10.1080/00224545.1993.9713950

Mintabae, K. M. (2010). Dukungan sosial orangtua dan konsep diri dengan motivasi berprestasi ditinjau dari jenis kelamin (studi pada mahasiswa Universitas Halmahera). [Tesis. Universitas Kristen Satya Wacana].

Partosuwido, S. R. (1992). Penyesuaian diri mahasiswa dalam kaitannya dengan konsep diri, pusat kendali dan status perguruan tinggi. [Disertasi (tidak dipublikasikan), Universitas Gadjah Mada].

Putra, R. L., \& Nurhadianti, R. D. D. (2020) Adversity intelligence dan dukungan sosial orang tua dengan motivasi berprestasi siswa SMAN 6 Tambun Selatan. Jurnal IKRA-ITH Humaniora, 4(1), 1-10. https://journals.upi-yai.ac.id/index.php/ikraithhumaniora/article/view/613

Putri, E. P. (2014). Hubungan dukungan sosial orang tua, pelatih dan teman dengan motivasi berprestasi akademik dan motivasi berprestasi olahraga (basket) pada mahasiswa atlet basket Universitas Surabaya. Jurnal Ilmiah Mahasiswa Universitas Surabaya, 3(1), 1-11. https://journal.ubaya.ac.id/index.php/jimus/article/view/1747

Sarafino, E. P., \& Smith, T. W. (2011). Health psychology biopsychosocial interactions. John Wiley and Sons.

Santrock, J.W. (2003). Adolescence: Perkembangan remaja. Erlangga.

Setyaningrum, A. (2015). Pengaruh dukungan sosial orang tua terhadap motivasi berprestasi siswa 
kelas V sekolah dasar. Jurnal Pendidikan Guru Sekolah Dasar, 17(5), 1-10. http://journal.student.uny.ac.id/ojs/index.php/pgsd/article/view/1203/1075

Sohrabi, C., Alsafi, Z., O’Neill, N., Khan, M., Kerwan, A., Al-Jabir, A., Iosifidis, C., \& Agha, R. (2020). World Health Organization declares global emergency: A review of the 2019 novel coronavirus (COVID-19). International Journal of Surgery, 76, 71-76. http://doi.org/10.1016/j.ijsu.2020.02.034

Suryabrata, S. (2006). Psikologi pendidikan. Raja Grafindo Persada.

Verkuyten, M., Thijs, J., \& Canatan, K. (2001). Achievement motivation and academic performance among Turkish early and young adolescents in the Netherlands. Genetic, Social, and General Psychology Monographs, 127(4), 378-408.

Winkel, W. S. (1992). Psikologi mengajar. Media Abadi.

Wiprana, Y. V. (2006). Motivasi berprestasi dalam bidang akademik pada mahasiswa pekerja sales promotion girl ditinjau dari konsep diri. [Skripsi (tidak dipublikasikan), Universitas Katolik Soegijapranata].

Zanobini, M., \& Usai, M. C. (2002). Domain-specific self-concept and achievement motivation in the transition from primary to low middle school department of anthropological. Journal Educational Psychology, 22(2), 203-217. https://doi.org/10.1080/01443410120115265 